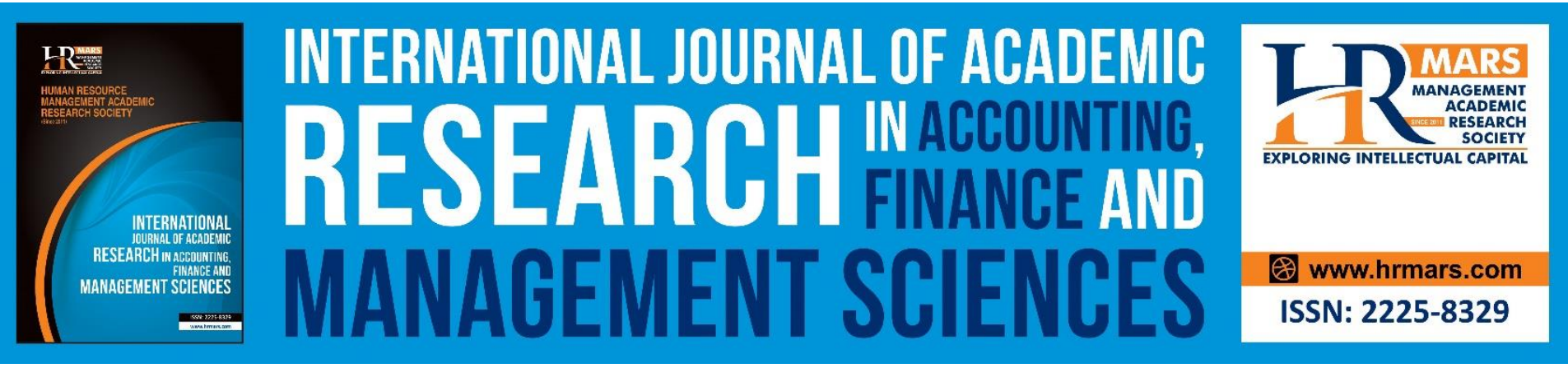

\title{
Microfinance Institution's Sustainability and Mission Drift: An Empirical Review
}

Abul Bashar Bhuiyan, Aza Azlina Md Kassim, Md Jafor Ali, Muhammad Saad,
Abu Dzar Muhammad Rus

To Link this Article: http://dx.doi.org/10.6007/IJARAFMS/v10-i3/7873

DOI:10.6007/IJARAFMS /v10-i3/7873

Received: 10 June 2020, Revised: 16 July 2020, Accepted: 20 August 2020

Published Online: 28 September 2020

In-Text Citation: (Bhuiyan, et. al., 2020)

To Cite this Article: Bhuiyan, A. B., Kassim, A. A. M., Ali, M. J., Saad, M, Rus, A. D. M. (2020). Microfinance Institution's Sustainability and Mission Drift: An Empirical Review. International Journal of Academic Research in Accounting, Finance and Management Sciences. 10(3), 349-364.

\section{Copyright: (c) 2020 The Author(s)}

Published by Human Resource Management Academic Research Society (www.hrmars.com)

This article is published under the Creative Commons Attribution (CC BY 4.0) license. Anyone may reproduce, distribute, translate and create derivative works of this article (for both commercial and non-commercial purposes), subject to full attribution to the original publication and authors. The full terms of this license may be seen at: http://creativecommons.org/licences/by/4.0/legalcode

Vol. 10, No. 3, 2020, Pg. 349 - 364

Full Terms \& Conditions of access and use can be found at http://hrmars.com/index.php/pages/detail/publication-ethics 


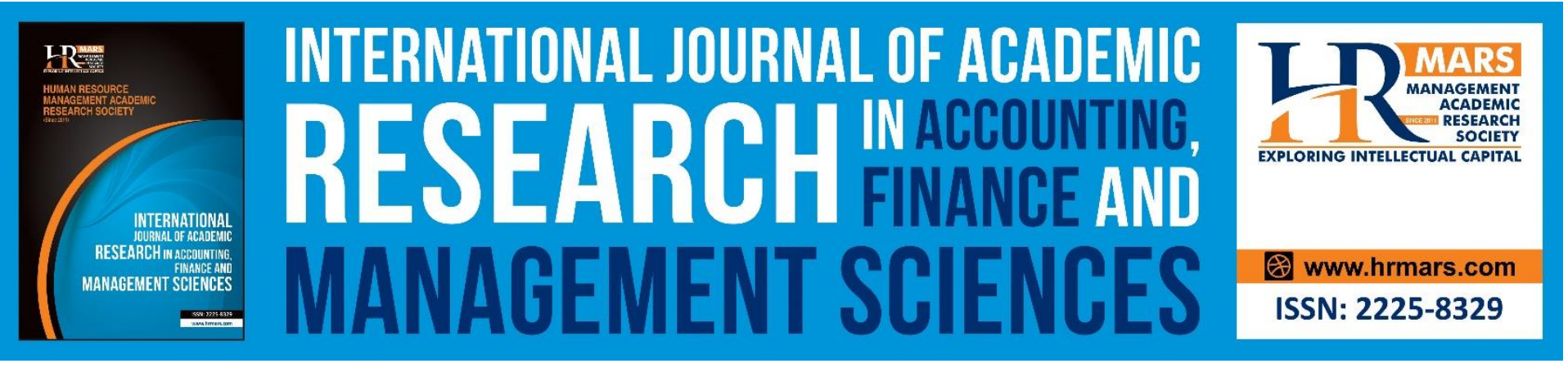

\title{
Microfinance Institution's Sustainability and Mission Drift: An Empirical Review
}

\author{
Abul Bashar Bhuiyan ${ }^{1}$, Aza Azlina Md Kassim², Md Jafor Ali ${ }^{3}$, \\ Muhammad Saad ${ }^{4}$, Abu Dzar Muhammad Rus ${ }^{5}$ \\ 1,3,5Faculty of Business and Accountancy, Universiti Selangor, Malaysia, ${ }^{2}$ Faculty of Business
} Administration, Islamic University, Bangladesh, ${ }^{4}$ Fast School of Management, National University of Computer and Emerging Sciences, Karachi

Email: aza_azlina@unisel.edu.my

\begin{abstract}
Since dawning as methodical approach, microfinance is termed as one of the utmost anti-poverty mechanisms which is discharging financial and associated services to underprivileged who(s) were kept at surface by conventional financial institutions. However, sustainability of microfinance institutions (MFIs) is also imperative for sustainable economic development of the outreach and institution itself. To secure sustainability, every so often, MFIs are more accentuating on financial mission instead social mission inducing mission drift. The study aims corroborating the position of sustainability and mission drift in MFIs with the context of empirical reviews. This is a review study adopts re-examining the determinants of mission drift and its impact on sustainability of MFIs in alleviating poverty, from the course of existing and prominent research works and literatures. The study reveals that financial self-sufficiency (FSS), operational self-sufficiency (OSS), operational efficiency (OE) and wide coverage of depth and breadth of outreach warrants sustainability of MFIs and absence of subsidized fund, commercialization, higher average loan size, lack of innovations and supervisory measures, scaling up process and lower coverage of depth and breadth of outreach etc. pave the way for mission drift. We recommend that bigger outreach, vibrant and comprehensive regulatory policy, organizational commitment and true outreach base help achieving social mission as well as financial mission of MFIs.
\end{abstract}

Keywords: Microfinance Institutions, Sustainability, Mission Drift, Outreach.

\section{Introduction}

Since the outset of the Microfinance, also acquainted as Microcredit, it is providing financial and allied services to poor or marginalized income segment of the society who are, otherwise, kept outside by the formal financial services institutions (Abrar, 2019; Hudon, Labie, \& Reichert, 2018; Serrano-Cinca \& Gutierrez-Nieto, 2014). Due to having wide variety of incapability of conventional and traditional financial institutions to credit effectively the low-income people of the world, the microfinance appears like a social enterprise to uplift their financial position (World Bank, 
2007).Why the poor people across the globe are poor? The obvious answer is missing access to the financial facilities (Coleman, 1999; Fletschner, 2009; Karnani, 2007). Microfinance Institutions provide small scale financial services, savings, loans, insurance etc. to support entrepreneurial initiatives of the underprivileged who are left aside by the traditional and mainstream financial institutions (Amin, Qin, Rauf, \& Ahmad, 2017; Jha, 2017; Lopatta, Tchikov, Jaeschke, \& Lodhia, 2017; Quayes \& Hasan, 2014).

In fact, the Microfinance institutions are the social enterprise dispatching financial services for the impoverished families along with their earnings breeding actions (Beisland, D'Espallier, \& Mersland, 2019; Ghosh \& Guha, 2017; Segun, 2017). Beside the credit services, MFIs are organizing and mobilizing the resources in providing financial and allied services to the low income people, particularly vulnerable women for worthwhile and sustainable productive revenue generation ventures enabling them to shrink their privations (Hudon et al., 2018; Wang \& Ran, 2019). Likewise, MFIs are building opportunities and conducting various life skills training programs contributing to income and employment generation in rural areas for the underprivileged (Martinez \& McKay, 2011; Yunus \& Weber, 2008). After all, MFIs are acting a pivotal role in eradicating poverty, increasing household income, self-empowerment, building of assets, food security and basic subsistence (Yunus \& Weber, 2008). Moreover, Micro Finance Institutions are encircling the destitute and low income people by safety net such as savings, insurance coverage, life skills training and entrepreneurial activities (Bank, 2007; Copestake, 2007; Fletschner, 2009; Yunus \& Weber, 2008).

By this way, MFIs are playing an important role in creating a sustainable developed society by alleviating poverty and that is the ultimate mission of it (Morduch, 1999). While providing the financial services, MFIs are charging their clients for microcredit without collaterals, financial services and for other services. These revenues of MFIs helping to become financially sustainable organization for continuous services to the destitute society. Without a doubt, sustainable MFIs are requisite for sustainable development (Kar, 2013; Ochieng \& Odondo, 2018; Yunus \& Weber, 2008).

Sustainable MFIs are imperative for sustainable economic development of the poor. Not only Sustainability of MFIs is significant for the institution itself, but also for the whole economy due to their impact in poverty alleviation (Saad et all. 2018). Usually, Sustainability of MFIs is recognized as institutions affordability to cover its both financial, operating and financing expenditures from its generated revenues (Rahman \& Luo, 2012). Institutions ability to utilize its financial resources and borrowings on fair rates for delivering its services on consistent way are termed as Sustainability of MFIs (Chaves \& Gonzalez- Vega, 1996). Okumu (2007) viewed sustainability of MFIs as its capability to produce enough leverages by covering its operational expenses (Rao \& Fitamo, 2014) simply defined sustainability of MFIs as ability to conduct its operation as a going concern enterprise by delivering financial services to marginalized community which was overlooked by the traditional financial institutions .In the developing counties, now a days, sustainable MFls are indispensable for financial services to serve the poor of the remote areas. Therefore, the sustainability of MFIs are stated as the achievement of twin aspect mission 1) attaining financial self-sufficiency as well 2) roll out to the maximum number of poor (well-known as outreach) and is commonly recognized as Ultra Poor or double bottom line (Dunford, 2000; Guntz, 2011). Moreover, sustainability of MFIs are also essential for cost 
management \& controlling, institutional development, experimentation, innovations and to attain poverty alleviation goal (Tehulu, 2013; Vinelli, 2002).

While serving the maximum numbers of poor at affordable interest rate, the MFIs should keep eyes on looking after the ways of survival and not to more dependent on subsidized funds of donor agencies and governments (Abrar, 2019). But determination of fair level interest rate is still an ongoing debate. Few market leader MFIs are charging their clientele with high interest rates and bagging excessive profit and have raised the question of how to define a fair profit level for social enterprise (Hudon et al., 2018). By serving the poor clients and generating profit to maintain institutional sustainability; it is an inborn puzzle in the fundamental interrogation of microfinance industry (Wang \& Ran, 2019). Over the time, however, the MFIs have shifted its paradigm from primary purpose of reaching out to the underprivileged to profit maximization (Dichter \& Harper, 2007). Microfinance experts and researchers, globally, have debated that profit maximization pressure create mission drift easily (Dillard, Pullman, Epstein, \& Yuthas, 2010). Mission drift follows the microcredit client's swings from the poorer to wealthier ones (Cull et al. 2007). The deviation in MFIs mission drifts intent of serving the poorest of the poor, a complete violation of business ethics of MFIs (Serrano-Cinca \& Gutiérrez-Nieto, 2014). Abrar and Javaid (2014) viewed that the Microfinance Institutions are truly required a balanced tradeoff between the social and financial objectives (Abrar, 2019).

\section{Background of the Study Sustainability of Microfinance Institutions}

Sustainability is the basis of the MFIs to alleviate the poverty across the world (Kimando, Kihoro, \& Njogu, 2012). The term Institutional Sustainability refers to the microfinance Institutions capacity to cover with all of its costs by earning interest and any other earnings paid by the customers. Experts have defined sustainability in different perspectives: on the basis of banker viewpoint on the MFls is sustainable when it's all operating income exceeds operating cost (Sharma \& Nepal, 1997). Usually, Sustainability of MFIs is recognized as institutions affordability to cover its both financial, operating and financing expenditures from its generated revenues (Rahman \& Luo, 2012).

Sustainable MFIs are the crucial part of the economic system if it can continue its operation even after grants from the donor agencies or soft loans are no longer available (Armendariz, D'Espallier, Hudon, \& Szafarz, 2013). Rao and Fitamo (2014) simply defined sustainability of MFIs as ability to conduct its operation as a going concern enterprise by delivering financial services to marginalized community which is overlooked by the traditional financial institutions. Sustainability of MFIs are used to measure the ability to conduct a program with own resources to yield outputs that are meaningful for beneficiaries and other stakeholders (Woller, Dunford, \& Woodworth, 1999). Sustainability of MFIs is concentrated on some measurements depending on situations such as Mission sustainability, program sustainability, Operational Sustainability, and financial sustainability (Schreiner, 2000). The sustainability dimensions support the enterprise keeping it on preferred lane for the long time (Mahajan \& Nagasri, 1999). Dunford (2000) and Guntz (2011) explained that the sustainability of MFIs is stated as the achievement of twin aspect mission 1) attaining financial self-sufficiency as well 2) roll out to the maximum number of poor (outreach). 


\section{Financial Sustainability or Financial Self Sufficiency}

Every Microfinance Institution gives every effort for the goal of achieving institutional financial sustainability. The toughest trials confronting, especially in developing countries, by the MFIs is to reach in a position of financial sustainability (Martina \& Karel, 2018; Wondirad, 2018). Supposedly, the financial sustainability facilitate the MFIs to cover all administrative costs and to highlight the functions to attain missions, without undertaking any conditional negotiations with donors that may or may not support vision or overall cost percentages (Leon, 2001). Ayayi and Sene (2010) and Rao and Fitamo (2014) stated that microfinance institution would be self-sufficient if it makes enough profit to survive without any aid, as debt and grants have negetive co-relation with MFIs sustainability (Sekabira, 2013). Usually, financial sustainability of MFIs is recognized as institutions affordability to cover its expenditures from generated revenues (Rahman \& Luo, 2012). To measure the MFIs performance, the Micro banking bulletin (MBB) accepted financial sustainability or financial self-sufficiency (Manos \& Yaron, 2008). The MFI is in a sustainable position, when it covers hundred percent cost through operation (Churchill \& Frankiewicz, 2006). The major pillars for the financial sustainability of MFIs are strategic and financial planning, income diversification, sound administration and financial management and own sufficient income generation (Leon, 2001).

\section{Operational Sustainability or Operational Self Sufficiency}

The operational sustainability makes an organization healthy, vibrant, going and successful concern (Gibson, 2012) described the different dimensions of the operational sustainability in the MFIs such as institutional sustainability, mission sustainability, program sustainability, human resource sustainability, financial sustainability, market sustainability, legal and policy environment sustainability, impact sustainability etc. operational self-sufficiency (OSS) shows an indication, whether a MFIs is producing enough revenue to cover financial \& operational costs along with loan loss provisions. Operational self-sufficiency is stated always in percentage term by balanced fine-tuning of total operational income and total operational costs (Esampally \& Joshi, 2016). If the operational self-sufficiency ratio is more than hundred percent then the institution is operationally sustainable (Churchill \& Frankiewicz, 2006). However, the operational self-sufficiency measures the relationship between operational income and expenditures of MFIs.

\section{Outreach}

The central function of MFIs is to disburse credit to the actual poor, therefore, success deeply rely on its outreach performance (Quayes, 2015; Wang \& Ran, 2019). The word outreach commonly implies two dimensions: depth and breadth of outreach (Kaur, 2014). Depth and breadth of financial and associate services such as Savings, loan provisioning, money transfer, insurance and payment services of MFIs are used to weigh the outreach performance (Rao \& Fitamo, 2014). Here to serve the ultra-poor is depth of outreach, but covering the large number of poor people denotes the breadth of outreach (Brau \& Woller, 2004; Schreiner, 2002). Microfinance expert, Schreiner (2002) described the six dimension of outreach as deapth , worth, cost, width, length and scope of outreach. On the contrary, Yaron (1992) proposed seven dimension to measure outreach that is almost alike Schreiner (2002). Whatever explained by experts 
INTERNATIONAL JOURNAL OF ACADEMIC RESEARCH IN ACCOUNTING, FINANCE AND

MANAGEMENT SCIENCES

Vol. 10 , No. 3, 2020, E-ISSN: $2225-8329$ @ 2020 HRMARS

regarding outreach, it states poverty level of the client served and the scale of operations of the MFIs.

\section{Concept of Mission Drift}

Over the time, however, the MFIs have shifted its paradigm from primary purpose of reaching out the underprivileged to profit maximization (Dichter \& Harper, 2007). Mission drift follows the microcredit client's swings from the poorer to wealthier ones (Cull et al. 2007). It is apparently seen that, to become financially sustainable, MFIs are often deviated from main mission of serving the maximum number of poor clients (Mersland \& Strøm, 2010). This deviation from its original goal is commonly known as mission drift (Mia \& Lee, 2017; Serrano-Cinca \& Gutiérrez-Nieto, 2014). Microfinance organization leading towards wealthier clients rather target customer, i.e. poor, is committing drift to its mission and weakening outreach (Schreiner, 2002; Woller et al., 1999). Mission drift contributes in increasing average loan size motivated by profit seeking behavior of MFIs and increasing profitability by reducing operational cost (Armendariz \& Szafarz, 2011). Research shows that MFIs covering superior breadth and depth of outreach have no sign of mission drift (Tchakoute-Tchuigoua, 2010).

\section{Micro Finance Sustainability and Mission Drift}

MFIs sustainability is the combination of fine-tuning among financial self-sufficiency (FSS), operational self Sufficiency (OSS) and depth and breadth of outreach. But the Wel-farist campaign against for higher interest rate which brings financial sustainability success by interest charging to the outreach. On the contrary, Institutionalists advocate that there is neither evidence of failure of non-affordability of higher interest rate by the poor nor the poverty level of outreach and financial sustainability are negatively correlated. Despite the both groups seem to be paradoxical; the debate continues to exist. However the argument goes; all human being particularly the poor and vulnerable group should have guaranteed access to the financial services as they are required (Abdulai \& Tewari, 2017; Hudon et al., 2018). This has been further strongly reinstated in the Sustainable Development Goals (SDG) that "by 2030, [we must] ensure that all men and women, in particular the poor and the vulnerable, have equal rights to economy resources, as well as access to basic services, ownership and control over land and other forms of property, inheritance, natural resources, appropriate new technology and financial services, including microfinance". Outreach and mission drift are intertwined each other, where the demand of financial sustainability of MFIs and financial inclusion of outreach is unmet so the case of mission drift is prevalent (Schreiner, 2002).

\section{Methodology of the Study}

This is a review study adopted for re-examination of the determinants of mission drift and its impact on sustainability of MFIs in alleviating poverty from the course of the existing and prominent research works and literatures. To do so, we conducted general searching of research works and literatures in the name of mission drift, outreach, financial sustainability, operational sustainability and MFIs sustainability in the online data base sources such as Google Scholars, Spingers link, Wiley, Science Direct, JSTOR, Emerald full text, Scopus, and EBSCO HOST etc. From this general searching, we found a good number of research papers, journal articles, 
conference and any other type of works, in which we have gone through to select which articles or research papers require including in the review of this paper. Subsequently reading and analyzing thoroughly the most appropriate articles, we have collected those were found as the best fit within objectives of the present issue about microfinance institutions sustainability and Mission drift. The review has examined on the basis of objectives, methods and findings accordingly of the all collected empirical studies.

\section{Empirical Review of The Literature}

This empirical study reviewed the literatures on various aspects that influence the parameters of sustainability and mission drift on MFIs. This study captures wide variety of prominent literatures from experts exploring various factors influencing the microfinance sustainability framework.

\section{Some of the studies are as hereunder}

Wang and Ran (2019) studied the sustainable contrivances of MFIs through a comprehensive case study on Rishenglong Ltd (RSL), a MFI in Pingyao, China. In this paper, they have extensively analyzed the operational features and insights of Rishenglong Ltd (RSL) in balancing the operational and financial mission and how it travelled to sustainable ground. In this article the authors suggested that the mission paradox challenged by MFIs might be efficiently mitigated by putting more significance on survivality or social mission than thrive ability or financial mission by a set of well befitting instruments such as localized mode including ancient traditional culture and local value system, specified post loan services mechanisms, philosophy of anti-diversification, localized operational model, the powerful regulatory guideline from different levels of government and normative forces from local industry association, borrower selection through credit group, credit culture, solidarity lending, moral evaluation and reputation mechanism, meager profit orientation approach etc.

Churchill (2019) analyzed the position of trade-off between MFIs financial sustainability and outreach using the data of 1595 MFIs from 109 countries around the world. The research found that the evidence of trade-off relationship between MFIs financial sustainability and outreach depth works in both direction. In this paper the author recommended that the MFIs sustainability has strong negative impact on depth of outreach so the MFls should put more importance on depth of outreach than financial sustainability. The researcher further recommended that it has a greater significance of differentiating between the outreach breadth and depth. This will distinctly enable the MFI authorities and policy makers in understanding the social performance in terms of number of poor client served as well as outreach quality.

Meanhile, Pedrini and Ferri (2016) conducted a research work for analyzing the relationship among mission drift, financial performance and outreach of a dataset on Microfinanza Rating of 194 MFIs from the year 2001 to 2010 with mixed effect regressions. The study showed that a trade-off exist between financial performance and outreach in MFIs activities. The analysis recommended that mission drift positively impacts on financial performance but it reduces outreach depth and breadth. Darko (2016) studied whether MFls in Uganda follow a developmental objective by expanding their access to poorer districts on 118 MFIs over the period from 2009 to 2013 by using static count data model and dynamic regression approach. The 
research found that MFIs in Uganda are more likely to target richer districts during earlier years and then progressed to the poorer district over the time. This finding suggested that for sustainability of financial performance, MFIs first establish branches in better-off districts and then to outreach. The study also recommended that access to the capital market for the efficient MFIs may widen the outreach horizon to the unbanked and poorest segments. Kulkarni (2017) studied the developments in financial indicators demonstrating portfolio risk, financial efficiency, productivity and outreach in MFIs in India. The main objective of this paper was to justify the relationship between financial performance and outreach by using panel data method from data collection of $46 \mathrm{MFIs}$ for the period of 2005 to 2014. The study found no evidence of trade-off between efficiency and outreach. Also, the researcher pointed out that the MFIs are moving from unprofessionally managed institution to professionally run, investor-friendly, profit conscious, or rather profit-driven organizations.

In a different study, Caserta and Reito (2013) analyzed the very recent trend of outreach and mission drift in the activities of MFIs. Their interpretation showed that micro finance institutions can rationally select the both poor and wealthier borrower. In the first case, the very poor entrepreneurs may receive low-average loans under a group-lending arrangement on contrary the wealthier entrepreneurs may receive high-average loans under an individual liability scheme whether there is a "mission drift" towards richer borrowers which are more profitable for lenders. Serrano-Cinca and Gutierrez-Nieto (2014) analyzed the synthesis of micro finance, long tail (outreach) and mission drift position by using the $80 / 20$ principles on a MFI database from years 2006 to 2010. This paper explained that the outreach are situating at the long tail of the wealth distribution channel as such the MFIs are reluctant to serve them for its high administrative costs, lack of deposits etc. This reluctance towards long tail committing mission drift. This paper also presented a model to explain microfinance mission drift with tested hypotheses.

Kar (2013) analyzed the effect of profitability on depth of outreach in MFIs and mission drift using a unique panel database containing observations of 4 to 6 years from $409 \mathrm{MFIs}$ in 71 countries. The study found diversified result and mostly failed to confirm the mission drift hypothesis if it is defined as a trade-off between profitability and depth of outreach. The author observed that checking for mission drift in microfinance in a more accurate way requires looking for changes in the behavior of the same MFI over time, but it was difficult to conduct as appropriate data were unavailable. Macdonald (2010) examined the mission drift position in MFls particularly in ASA, Association for Social Advancement, one of the largest microfinance institutions in the world on the basis of its aim and functions. The study argued that the actual position of mission drift should the argued in terms of the organizations own documented action and performance to the outreach. The study found that the organization is delivering service to its intended clients as per documented aims. But ASA formulated its aim so technically that the majority of the population eligible to this structure. The author further recommended that any organization whether or not drifting from its mission is related to justification of objective clientele.

Khan et al. (2016) studied level of mission drift in Pakistani MFIs by using various financial measures such as sustainability, credit methodology, female borrowers, leverage, age of institutions, profit status and regulations of institutions. The results revealed that, credit methodology and age of the institution negatively affects depth of outreach while leverage, female borrowers and profit status have positive impact on depth of outreach. The findings of the research 
suggested that in Pakistan, depth of outreach can be successful if institutions lend smaller loans to the outreach. Arrassen (2017) conducted a research on the contributing factors of the MFIs financial sustainability \& profitability and social performance simultaneously evaluated the tradeoff they confront. The research was carried on a sample of $120 \mathrm{MFIs}$ over the period of 2000 to 2009 by using random effect method and found that the financial performance of MFIs influenced, predominantly, by portfolio quality, financial expenses and wages on the other hand the social performance of MFIs influence, mainly, by lending methodology institutional form and depth and breadth of outreach. The paper advocated that commercialization of MFIs are not vulnerable to mission drift rather likely to follow by the MFIs, who has never been in the foremost focus of the poverty alleviation.

Mia and Lee (2017) directed a research work which evaluated the influences and relations of commercial funds and mission drift in MFIs. In this research, static and dynamic panel data estimation techniques were used to analyze the data collected from 169 microfinance institutions from the period of 2009 to 2014. The study revealed that mission drift is most evident, when the MFIs use the commercial funds. They further suggested that the commercial funds influence MFIs towards increasing average loan size against GNI and commercial interest. The researchers also recommended that the mission drift may be convinced by other factors such as macroeconomic conditions and regulatory policy and environment. Abrar and Javaid (2014) conducted a research work which examined the commercialization trend and drifting size by using average loan size as proxy of mission drift with operational self-sufficiency as profit measure, productivity as cost measure and repayment risk as independent variables on collected data from 72 countries of six regions of the world for the years 2003 to 2009. The study found that profitability and risk are positively related with average loan size whereas cost is inversely related with size of loan. The study further suggested that commercialization bringing the MFls towards mission drift and disregarding the goal of poverty alleviation.

Jia, Cull, Guo and Ma (2016) examined the relationship between commercialization of MFIs and mission drift by using a unique data set on the largest nongovernmental MFIs in China. The study found that commercialization guides the MFI and its loan officers towards collecting larger loans. The researcher further recommended that the career background in farming or local credit officers were better able to maintain outreach to poorer borrowers. Deb (2018) found that absence of adequate subsidized fund MFIs enticed to commercial funds steer towards commercially oriented and profit motivated for financially sustainable. The paper also found that fierce competition and commercialization assisting more low income clients to get into formal financial systems. Beside these, this trend also alluring the MFIs towards mission drift from social mission. This paper recommend that, despite commercialization and the fierce competition MFIs needs to pay heed to social mission along with financial mission equally.

Armendariz et al. (2013) conducted a research work to draw a relationship between the subsidized fund uncertainty and mission drift of MFls using data from rating agencies. The researchers developed a model and showed that if the subsidized fund is shrunken; the possibilities of mission drift escalate. The study found a positive relationship between subsidy uncertainty and the interest rate charged to borrowers that truly lead mission drift at the end of the day. Biancini, Ettinger and Venet (2019) analyzed relationship of mission drift with MFIs and external funding institutions with the help of contract theory approach. The study finds that penetration of new 
force in the MFI dimension as funding institutions (public or private) always enhance the opportunity for aberration from the social mission and ultimately cause drifts from its mission leading to reduce the share of poorer borrowers. The study also suggests that the funding institutions need to pay incentives to the MFI for lending to the desired level of poor borrowers. Ranjani and Kumar (2018) studied to investigate empirical evidence of social mission drift among 211 Indian MFIs for the period of 1985 to 2014 by using several proxies. The authors of the study found that the institutional efficiency, average loan balance and higher lending rate are the main reasons for the higher profitability of the MFIs which is drifting the social mission. The paper also recommend that large and efficient MFIs should be given wide right to use economical funds to keep them in course and financially sustainable along with averting mission drift.

Brown, Guin and Kirschenmann (2012) identified the impact of gradual commercialization of MFIs towards drifting from its mission. The study examined the household level dataset of four countries in South-East Europe in 2006 and 2010 to find out that microfinance banks do expand their domain of finance as compared to conventional retail banks and suggested that there should not be worry by decision makers as because at the maturity level all the MFIs are surge for up market and the cumulative effort does not indicate the substantial mission drift in social performance. The study recommends that to enhance the sustainability of their interventions, bilateral and multilateral donors should target their support to those institutions which are financially sustainable. Getu (2007) evaluated whether commercialization of MFIs programs lead to mission drift. The author stated that MFIs are being commercialized day by day although commercialization of MFIs is doubted in respect of social mission, whereas a segment hailed the movement and others are branded it as mission drift. The study recommended that if commercialization is justified, argumentative and need based then it can be added as blessings than blight for organizational mission accomplishment.

Armendariz and Szafarz (2009) examined the mission drift in MFls with a framework and under which conditions mission drift can be appeared. The authors claimed that the mission drift is not emerged for progressive lending or cross- subsidization but cause for the chemistry between their own missions. With their developed framework, the study exhibited that there is a subtle streak in between mission drift and cross-subsidization which is fostering deviation MFI's poverty reduction mission. The study further suggested that MFIs working with very small depth and outreach deceiving perceived as deviating from their mission. Saab (2015) conducted a research studied the impact of growth of MFIs on the economies of less developed countries in terms of poverty alleviation, creating more opportunities and better standards of living but the expectations of economic performance from the MFIs are far below. This paper extensively analyzed the link between financial development, MFIs borrowing and the interest rate spreads and the average loan size among others. The study recommended that the interest rate spread highly affect this sector and could lead to a mission drift.

Ometto, Gegenhuber, Winter and Greenwood (2019) examined the mechanisms, how social enterprise manage their missions and risk of mission drift while enterprise growing larger. The research showed that the social enterprises are initially successful in balancing its mission then failed in the bigger focus. The study suggested that the mission drift in the social enterprise could have been avoided in the larger enterprise if the contribution towards outreach is taken care and negotiated. Hishigsuren (2007) studied the effects of scaling up on the social mission of 
MFIs and proposed a methodology for measuring mission drift using a field research at Activists for Social Alternatives (ASA), a microfinance organization for poor women in countryside India. The outcome of the research showed that mission drift is not effect of deliberate decisions of management team or board rather it is consequences of the scaling-up process.

Gaudens-Omer (2018) examined MFIs mission drift problems and external regulatory restrictions by using portfolio model. In this paper, the researchers develop a static portfolio model for MFIs, which has dual mission; financial and social. This model emphasizes on solidarity return trade-off and degree of mission drift. This paper suggested that stiff regulatory issues lead the MFIs to mission drift. To control the mission drift the regulator may moderate the perceived risk. This paper additionally recommended that the regulator should inspire the use of financial innovations and organizational innovations to fortify the pro social behavior of MFIs. Arena (2007) conducted a research in the problem of mission drift in socially oriented MFIs on the basis of social corporate governance on two microfinance providers through the use of case studies and field research. The author argued that social corporate governance is premeditated towards organization's social and development goals contrasting with orthodox corporate governance appliance. The study found, when both governances is well-adjusted each other, helps minimizing tension between financial and social development goal and offer a solution to mission drift in microfinance systems.

Abeysekera, Oguzoglu and Le (2014) analyzed the trade-off between financial sustainability and outreach along with level of mission drift using static \& dynamic panel data modeling by data collected from 149 PCF institutions from Vietnamese MFIs. By using dynamic panel data model, the researchers found that there are evidences of mission drift in Vietnamese MFIs. The study also gave a justification that the level of found mission drift may not be applicable for the entire Microfinance system in Vietnam. Ebrahim, Battilana and Mair (2014) examined the challenges, such as governance, mission drift and accountability, were facing by the social enterprise and hybrid organization, combination of charity and donation, through the use of market mechanism. In this paper, the researchers conceptualized the key challenges of governance and accountability to multiple stakeholders. The paper also theorized to prioritize and align the objectives and interests in order to evade mission drift and to maintain organizational hybridity in social enterprise. Wagenaar (2012) conducted a research regarding achievement of financial selfsufficiency driving MFIs towards possible mission drift using panel date analysis of $1558 \mathrm{MFIs}$ over the period of 15 years. The research found that the MFIs transformed from non-profit to for-profit have significantly higher average loan sizes and a lower percentage of female borrowers than nonprofit MFIs. The research further suggested that outreach of MFIs also is significantly lower after transformation in terms of average loan and percentage of female borrowers than before.

\section{Conclusions and Recommendations}

Microfinance institutions are considered as the most effective social institution around the world in alleviating poverty since its evolution. Recently, an argument is in full swing that most microfinance institutions are deviating from its social mission and emphasizing more to the financial mission regarding sustainability issues resulting mission drift. This empirical review endeavor contributed towards ongoing debate on microfinance institutions sustainability and mission drift. To contribute to the existing literature, overall review apprehended and analyzed the 
influences of major determinants of microfinance institutions sustainability and mission drift and its implications towards poverty alleviation. The empirical reviews expose that MFIs sustainability and mission drifts consequences are interplay of specific determinants.

The indicators such as Financial Self- Sufficiency (FSS), Operational Self-Sufficiency (OSS), operational efficiency (OE) and wide coverage of depth and breadth of outreach are positively related to sustainability of MFIs. Financial self-sufficiency ensures sufficient income generation of institutions affordability to cover its expenditures from generated revenues in achieving institutional financial sustainability; operational self-sufficiency facilitates all-around MFIs institutional sustainability, and operational efficiency mobilizes the efficient usage of resources of MFIs. Furthermore, MFIs sustainability largely depends on depth and breadth of outreach performance. As such, MFIs sustainability is the combination of fine-tuning among financial self-sufficiency (FSS), operational self-sufficiency (OSS), operational efficiency (OE), and depth and breadth of outreach.

Else ways, while MFIs focus more on financial mission rather social or poverty reduction mission, the mission drift parameters exist in the forms of absence of subsidized fund, commercialization, higher average loan size, lack of innovations and supervisory measures, lack of accountability and good governance, higher rate of spread, profit seeking mentality of board and management and low coverage of depth and breadth of outreach etc. pave the way for mission drift in microfinance institutions. This study suggests that wider outreach, vibrant $\&$ comprehensive regulatory policy and true social commitment towards poorest of the poor help achieving social mission as well as financial mission of MFls. The study additionally suggests that the effect of up scaling process and fierce competition among the MFls has mixed impacts on mission drift and sustainability.

\section{References}

Abdulai, A., \& Tewari, D. D. (2017). Trade-off between outreach and sustainability of microfinance institutions: Evidence from sub-Saharan Africa. Enterprise Development and Microfinance, 28(3), 162-181.

Abeysekera, S., Oguzoglu, U., \& Le, T. T. (2014). Sustainability and mission drift: Do microfinance institutions in Vietnam reach the poor? Microfinance Institution. Springer.

Abrar, A. (2019). The impact of financial and social performance of microfinance institutions on lending interest rate: A cross-country evidence. Cogent Business \& Management, 6(1), 1-21.

Abrar, A., \& Javaid, A. Y. (2014). Commercialization and mission drift-a cross country evidence on transformation of microfinance industry. International Journal of Trade, Economics and Finance, 5(1), 122-125.

Amin, W., Qin, F., Rauf, A., \& Ahmad, F. (2017). Impact of MFls outreach on profitability. the case of Latin America. Public Finance Quarterly, 62(3), 348-361.

Arena, T. (2007). Social corporate governance and the problem of mission drift in socially- oriented microfinance institutions. Colum. JL \& Soc. Probs., 41, 269.

Armendariz, B., D'Espallier, B., Hudon, M., \& Szafarz, A. (2013). Subsidy uncertainty and microfinance mission drift. Available at SSRN 1731265.

Armendariz, B., \& Szafarz, A. (2009). Microfinance mission drift. Research Institute in Management Sciences. 
Armendariz, B., \& Szafarz, A. (2011). On mission drift in microfinance institutions The handbook of microfinance. World Scientific.

Arrassen, W. (2017). The determinants of MFIs' social and financial performances in sub- Saharan Africa: has mission drift occurred? Annals of Finance, 13(2), 205-235.

Ayayi, A. G., \& Sene, M. (2010). What drives microfinance institution's financial sustainability. The Journal of Developing Areas, 44(1), 303-324.

Bank, W. (2007). Finance for all? Policies and pitfalls in expanding access: World Bank.

Beisland, L. A., D'Espallier, B., \& Mersland, R. (2019). The commercialization of the microfinance industry: Is there a 'personal mission drift'among credit officers? Journal of Business Ethics, 158(1), 119-134.

Biancini, S., Ettinger, D., \& Venet, B. (2019). Mission drift in microcredit: A contract theory approach. Retrieved from https://hal.archives-ouvertes.fr/hal-02304352/

Brau, J. C., \& Woller, G. M. (2004). Microfinance: A comprehensive review of the existing literature. The Journal of Entrepreneurial Finance, 9(1), 1-28.

Brown, M., Guin, B., \& Kirschenmann, K. (2012). Microfinance commercialization and mission drift. Die Unternehmung, 66(4), 340-357.

Caserta, M., \& Reito, F. (2013). Outreach and mission drift in microfinance: an interpretation of the new trend. Economics Bulletin, 33(1), 167-178.

Chaves, R. A., \& Gonzalez-Vega, C. (1996). The design of successful rural financial intermediaries: Evidence from Indonesia. World development, 24(1), 65-78.

Churchill, C. F., \& Frankiewicz, C. (2006). Making microfinance work: Managing for improved performance: International Labour Organization.

Churchill, S. A. (2019). Microfinance financial sustainability and outreach: is there a trade- off? Empirical Economics, 1-22. doi.org/10.1007/s00181-019-01709-1

Coleman, B. E. (1999). The impact of group lending in Northeast Thailand. Journal of development economics, 60(1), 105-141.

Copestake, J. (2007). Mainstreaming microfinance: social performance management or mission drift? World development, 35(10), 1721-1738.

Darko, F. A. (2016). Is there a mission drift in microfinance? Some new empirical evidence from Uganda. Retrieved from https://www.econstor.eu/bitstream/10419/175500/1/1603.pdf

Deb, J. (2018). Competition and commercialisation of microfinance institutions: implications for the sector. International Journal of Business Ethics in Developing Economies, 7(2), 27.

Dempsey, K. (2012). Microfinance mission drift-a study of microfinance institutions in Asia and Latin America: University of Northern British Columbia (Canada).

Dichter, T. W., \& Harper, M. (2007). What's wrong with microfinance?: Practical Action Publishing Rugby.

Dillard, J., Pullman, M. E., Epstein, M. J., \& Yuthas, K. (2010). Mission impossible: diffusion and drift in the microfinance industry. Sustainability Accounting, Management and Policy Journal, 1(2), 201-221.

Dunford, C. (2000). The holy grail of microfinance:'helping the poor'and 'sustainable'? Small Enterprise Development, 11(1), 40-44. 
INTERNATIONAL JOURNAL OF ACADEMIC RESEARCH IN ACCOUNTING, FINANCE AND

MANAGEMENT SCIENCES

Vol. 10 , No. 3, 2020, E-ISSN: $2225-8329$ @ 2020 HRMARS

Ebrahim, A., Battilana, J., \& Mair, J. (2014). The governance of social enterprises: Mission drift and accountability challenges in hybrid organizations. Research in Organizational Behavior, 34, 81-100.

Esampally, C., \& Joshi, M. K. (2016). Operational self-sufficiency of select NBFC-MFIS of Andhra Pradesh. SMART Journal of Business Management Studies, 12(2), 1-17.

Fletschner, D. (2009). Rural women's access to credit: market imperfections and intrahousehold dynamics. World development, 37(3), 618-631.

Gaudens-Omer, K. T. (2018). A model of microfinance regulation in a mission drift context. Journal of Economics, 6(1), 53-62.

Getu, M. (2007). Does commercialization of microfinance programs lead to mission drift? Transformation, 24(3/4), 169-179.

Ghosh, C., \& Guha, S. (2017). Efficiency and mission drift-debate revisited in Indian Context Women's Entrepreneurship and Microfinance: Springer.

Gibson, A. B. (2012). Determinants of operational sustainability of micro finance institutions in Kenya. Unpublished MBA Project.

Guntz, S. (2011). Sustainability and profitability of microfinance institutions. CAIFD-Center for Applied International Finance and Development, Research Paper, 4.

Hishigsuren, G. (2007). Evaluating mission drift in microfinance: lessons for programs with social mission. Evaluation Review, 31(3), 203-260.

Hudon, M., Labie, M., \& Reichert, P. (2018). What is a fair level of profit for social enterprise? Insights from microfinance. Journal of Business Ethics, 162, 627-644.

Jha, D. K. (2017). An investigation of how changes to corporate governance in Nepalese microfinance institutions may increase outreach while maintaining their financial performance. The University of Waikato.

Jia, X., Cull, R., Guo, P., \& Ma, T. (2016). Commercialization and mission drift: Evidence from a large Chinese microfinance institution: The World Bank.

Kar, A. K. (2013). Mission drift in microfinance: are the concerns really worrying? Recent crosscountry results. International Review of Applied Economics, 27(1), 44-60.

Karnani, A. (2007). The mirage of marketing to the bottom of the pyramid: How the private sector can help alleviate poverty. California management review, 49(4), 90-111.

Kaur, P. (2014). Outreach and sustainability of microfinance institutions in India in pre and post Andhra Pradesh microfinance crisis in context of South Asia. Global Journal of Finance and Management, 6(6), 569-574.

Khan, W., Naz, A. D., Shah, I., Khan, F., Alam, A., \& Khan, M. N. (2016). Measuring mission drift in emerging economies: An evidence from Pakistan microfinance network. J. Appl. Environ. Biol. Sci, 6(6), 20-27.

Kimando, L. N., Kihoro, J. M., \& Njogu, G. W. (2012). Factors influencing the sustainability of micro-finance institutions in Murang'a Municipality. Asian Society of Business and Commerce Research.

Kulkarni, L. (2017). Financial efficiency versus social outreach of Indian microfinance institutions: mission drift or character shift? Journal of Social and Economic Development, 19(2), 323-340.

Leon, P. (2001). Four pillars of financial sustainability: Resources for success series. The Nature Conservancy, Arlington, Virginia, USA. 
Lopatta, K., Tchikov, M., Jaeschke, R., \& Lodhia, S. (2017). Sustainable development and microfinance: the effect of outreach and profitability on microfinance institutions' development mission. Sustainable Development, 25(5), 386-399.

Macdonald, B. (2010). Redefining mission drift in microfinance: Exploring the link between aims and actions at ASA. Enterprise Development and Microfinance, 21(3), 243-254.

Mahajan, V., \& Nagasri, G. (1999). Building sustainable microfinance institutions in India. Paper presented at the session on India: the emerging microfinance market. Frankfurt Seminar on New Development Finance.

Manos, R., \& Yaron, J. (2008). Measuring the performance of microfinance providers: an assessment of past and present practices. International Journal of Financial Services Management, 3(2), 171-187.

Martina, D., \& Karel, S. (2018). Microfinance industry: sustainability, outreach and impact. IJAME.

Martinez, M., \& McKay, C. (2011). Emerging lessons of public funders in branchless banking. CGAP, 72, 1-13.

Mersland, R., \& Strom, R. O. (2010). Microfinance mission drift? World development, 38(1), 28-36.

Mia, M. A., \& Lee, H.-A. (2017). Mission drift and ethical crisis in microfinance institutions: What matters? Journal of cleaner production, 164, 102-114.

Morduch, J. (1999). The microfinance promise. Journal of economic literature, 37(4), 1569-1614.

Ochieng, O. B., \& Odondo, A. J. (2018). Logit analysis of the relationship between interest rate ceiling and micro lending market in Kenya. International Journal of Economics and Finance, 10(8), $105-116$

Okumu, L. J. (2007). The microfinance industry in Uganda: sustainability, outreach and regulation. Stellenbosch: University of Stellenbosch.

Ometto, M. P., Gegenhuber, T., Winter, J., \& Greenwood, R. (2019). From balancing missions to mission drift: The role of the institutional context, spaces, and compartmentalization in the scaling of social enterprises. Business \& Society, 58(5), 1003-1046.

Pedrini, M., \& Ferri, L. M. (2016). Doing well by returning to the origin. Mission drift, outreach and financial performance of microfinance institutions. VOLUNTAS: International Journal of Voluntary and Nonprofit Organizations, 27(6), 2576-2594.

Quayes, S. (2015). Outreach and performance of microfinance institutions: a panel analysis. Applied Economics, 47(18), 1909-1925.

Quayes, S., \& Hasan, T. (2014). Financial disclosure and performance of microfinance institutions. Journal of Accounting \& Organizational Change, 10(3), 314-337.

Rahman, M. W., \& Luo, J. (2012). Sustainability of NGO-type microfinance service provider in Shaanxi, China: Peer with Grameen Bank, Bangladesh. African Journal of Business Management, 6(15), 5319-5327.

Ranjani, K., \& Kumar, S. (2018). An investigation of mission drift in Indian MFI. International Journal of Social Economics, 45(9), 1305-1317.

Rao, K. R. M., \& Fitamo, T. (2014). Concepts and measures of outreach and sustainability in microfinance institutions: A comprehensive literature review. Research Journal of Finance and Accounting, 5(21), 41-48.

Saab, G. (2015). Micro financing and their "mission drift" orientation the MENA Region case. Procedia Economics and Finance, 30, 790-796. 
Schreiner, M. (2000). Ways donors can help the evolution of sustainable microfinance organizations/comment les bailleurs de fonds peuvent-ils aider l'évolution soutenue des organisations de microfinance? Savings and Development, 24(4), 423-437.

Schreiner, M. (2002). Aspects of outreach: A framework for discussion of the social benefits of microfinance. Journal of International Development, 14(5), 591-603.

Segun, O. T. (2017). Microfinance Mission Drift In Nigeria. West African Journal of Monetary and Economic Integration, 17(1), 86-98.

Sekabira, H. (2013). Capital structure and its role on performance of microfinance institutions: The Ugandan case. Sustainable Agriculture Research, 2(526-2016-37778).

Serrano-Cinca, C., \& Gutiérrez-Nieto, B. (2014). Microfinance, the long tail and mission drift. International Business Review, 23(1), 181-194.

Tchakoute-Tchuigoua, H. (2010). Is there a difference in performance by the legal status of microfinance institutions? The quarterly review of economics and finance, 50(4), 436-442.

Tehulu, T. A. (2013). Determinants of financial sustainability of microfinance institutions in East Africa. European Journal of Business and Management, 5(17), 152-158.

Vinelli, A. (2002). Financial sustainability in US microfinance organizations: Lessons from developing countries. Replicating Microfinance in the United States, Washington DC, 2002, 137-165.

Wagenaar, K. (2012). Institutional transformation and mission drift in microfinance. University of Cambridge, Centre of Development Studies.

Wang, J., \& Ran, B. (2019). balancing paradoxical missions: how does microfinance rebuild a sustainable path in poverty alleviation? SAGE Open, 9(2), 2158244019857838.

Woller, G. M., Dunford, C., \& Woodworth, W. (1999). Where to microfinance. International Journal of Economic Development, 1(1), 29-64.

Wondirad, H. (2018). Competition and mission drift in microfinance: Does competition has a mission drift impact. J Bus Fin Aff, 7(324), 2167-0234.1000324.

Yaron, J. (1992). Successful rural finance institutions discussion. Washington DC: World Bank Paper.

Yunus, M., \& Weber, K. (2008). Creating a world without poverty: How social business can transform our lives: Playaway Digital Audio. 